\title{
ANTIMITOTIC AND GENOTOXICITY EFFECTS OF WILD LIBYAN ARTICHOKE Cynara cornigera LEAVES AQUEOUS EXTRACT
}

\author{
Yara El hasham \\ Botany Department, Faculty of Science, Benghazi University, Benghazi - Libya \\ Fauzia El garabulli \\ Botany Department, Faculty of Science, Benghazi University, Benghazi - Libya \\ Salem El shatshat* \\ Botany Department, Faculty of Science, Benghazi University, Benghazi-Libya
}

Article D0I: https://doi.org/10.36713/epra4067

\begin{abstract}
Allium cepa root tip cells were used to find out the effect of Cynara cornigera extract on chromosomal structure and behavior during cell division. To measure the mitotic index and chromosome aberration in treated cells. The root meristem cells were treated with different concentrations of Cynara cornigera leaves aqueous extract (0.1, 0.01 and $0.001 \mathrm{mg} / \mathrm{ml}$ ) for 4, 6 and 12 hours, respectively. The results indicate that aqueous extracts of C. cornigera plant have the ability to decrease the (MI) values with increasing the concentration at $(P<0.005)$. The treatments have caused different kinds of mitotic abnormalities and chromosomal aberrations, such as: Change percentage of mitotic phases, C-metaphase, Stickiness, Disturbed nuclear membrane, Highly condensation of prophase and Accumulation of cell in interphase.
\end{abstract}

KEY WORDS: Bioassay: Cynara cornigera: Leaf extract: Artichoke; Chromosomal aberrations.

\section{INTRODUCTION}

According to the World Health Organization (WHO), about $80 \%$ of developing countries use traditional folk medicines, $85 \%$ of which are plant extracts. Furthermore, the international center of commerce reported that medicinal plants are still vitally important in the preparation of pharmaceutical products (Fransworth, 1994; Nune and Caravalho, 2003).

Artichoke has been known since the $4^{\text {th }}$ century B.C. as a food and remedy. This plant was appreciated by the ancient Egyptians, Greeks, and Romans, who used it both as a food and as a medicine (for their beneficial effects against hepatobiliary diseases and as a digestive aid) (Marzi et al., 1975; Sonnante et al., 2002).
In Libya, 4 species of Artichoke are reported and they include Cynara cornigera, Cynara cadunculus, Cynara scolymus and the endemic Cynara cyrenaica (Jafri and El-gadi, 1983). Cynara cornigera is dwarf plant, 10-20(30) $\mathrm{cm}$ and it is flowering in Spring (Plate 1). This plant is distributed in the eastern part of Libya and using widely in folk medicine. Shortage and no enough information about its effect on human use was led to shade some light on this plant. There for, this study was aimed and designed to evaluate the antimitotic and antimutagenic activities of aqueous extract of the leaves of $C$. cornigera on $A$. cepa root tip cells to find out the effect of $C$. cornigera on chromosomal structure and behavior during cell division by studying the mitotic index (MI) in the treated cells. 


\section{EPRA International Journal of Research and Development(IJRD)}

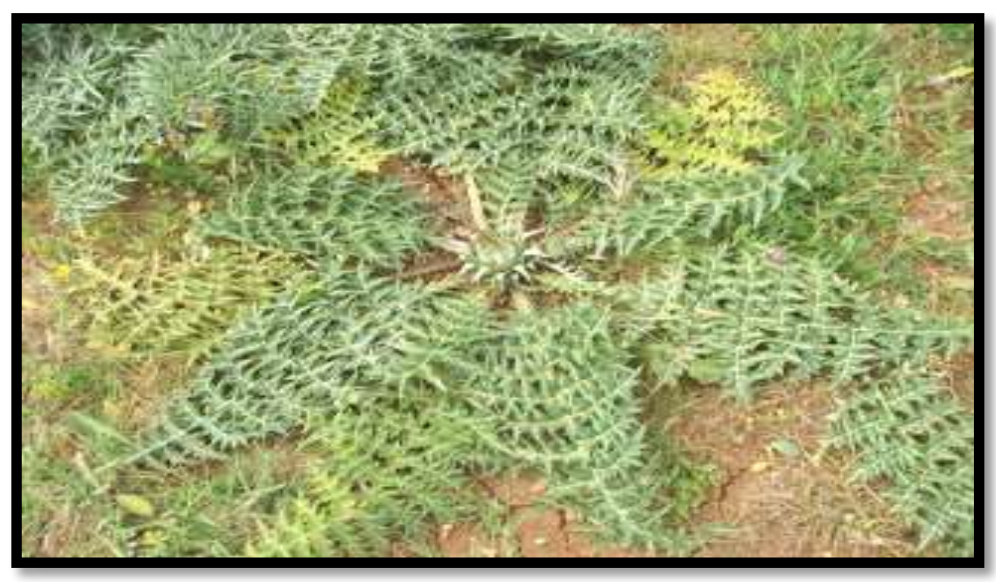

Plate (1) showed C. cornigera shrub plant in its wild habitat. Note the leaves and its flower in the middle with horns.

\section{MATERIALS AND METHODS}

Plant material: $C$. cornigera plants were collected from the borders of Benghazi city and identified according to the mentioned references, beside consultation of the Faculty of Science, Benghazi University, Libya. leaves were washed with distilled water, dried with filter paper in dark place. they were grind by electric blender and were stored as powder in dark flask until used. Commercial variety bulbs of the common onion (Allium cepa) were selected in shape and purchased from local market for plant bioassay.

Aqueous extract: $5 \mathrm{~g}$ of $C$. cornigera powder was added to $100 \mathrm{ml}$ boiled distilled water after cooling to $60 \mathrm{C}^{\circ}$. the content of the flask was shaken and left at room temperature (Tawab et al,2004). A buchner funnel lined with whatman No.1 filter paper was employed to filtrate the content of the flask. The filtrate was used as stock solution and three different concentration $(0.1,0.01$ and $0.001 \mathrm{mg} / \mathrm{ml})$ were prepared by serial dilution method (Jain and Sethi, 1991; Eltorki, 2006; Iranbakhsh et al., 2010).

Procedure of plant chromosomes technique: The preparation of plant chromosome achieved using standard methods described by (Grant, 1982), with minor modification.

Onion bulb germination and treatment: Onion bulbs were grown in distilled water at room temperature $\left(25 \pm 2 \mathrm{C}^{\circ}\right)$ in the darkness. They were placed in small $(50 \mathrm{ml})$ glass cups containing distilled water for approximately 3 to 4 days, when the primary root tips were $0.5-1.5 \mathrm{~cm}$ long, the bulbs were transferred to clean and dried containers included the treatments with a series of concentration. In this experiment two groups were used. group 1 included negative control (distilled water) and positive control treated only with colchicines solution
$0.05 \%$. In treated samples $5 \mathrm{ml}$ of colchicines solution $0.05 \mathrm{mg} / \mathrm{ml}$ were added to each treatment for 3 hours prior to harvesting except the negative control. The group 2 treatment with series of concentration stock solution, $0.1,0.01$ and 0.001 for 4 , 6 and $12 \mathrm{~h}$. The controls were treated with distilled water only. Ten root tips were cut and examined for each treatment, the experiment repeated for five times.

Fixation and slide preparation: For cytological preparation, the root tips were fixed in $95 \%$ ethanol /glacial acetic acid $3: 1(\mathrm{v} / \mathrm{v})$ from 1 to $24 \mathrm{hrs}$. at $5 \mathrm{C}^{\circ}$. The technique which use is described by Fiskesjö (1994). Slides were prepared using the aceto-orcein squash technique, by hydrolyzing the root tips in $1 \mathrm{~N}$ $\mathrm{HCL}$ at $60 \mathrm{C}^{\circ}$ for $12 \mathrm{~min}$. and stained with acetoorcein stain for $45 \mathrm{~min}$. The meristematic region of the root was removed and washed with $45 \%$ glacial acetic acid on glass slide and squashed with flattened glass rod in Glycerol and mounted with cover slip and temporary sealed with clear finger nail polish. Slides from each treatment examined by light microscope under $40 \mathrm{x}$ and $100 \mathrm{x}$ to find out the mitotic aberrations. The mitotic index MI was calculated as the percentage of dividing cells to the total number of cells examined. Abnormality cells was calculated as the percentage of abnormal cells to the total number of cells examined.

Data analysis: The data of mitotic index MI and Cmetaphase of plant chromosomes technique were analyzed by one way analysis of variance (ANOVA), Multiple comparisons were performed by least significance (LSD) using statistical package for social science (SPSS) with significance level less than 0.05 $(\mathrm{P}<0.05)$. 


\section{SJIF Impact Factor: 6.260| ISI I.F.Value:1.241| Journal DOI: 10.36713/epra2016 \\ EPRA International Journal of Research and Development(IJRD)}

\section{RESULTS}

Antioxidant activity of $C$. cornigera leaves aqueous extracts

The effects of $C$. cornigera aqueous extract on mitotic index (MI) and c-metaphase of $A$. cepa root tip cells at different exposure time intervals are illustrated in table (1). The obtained data showed significant differences between groups and within group $(p<0.005)$. The results of short hours treatments $(4$ hours) showed significant differences, decrease in MI by decreasing the plant extract concentration compared to (negative and positive) control. Lowest mitotic index values were in samples treated with 0 . 001 plant extract, its value was $7.49 \%$ compared to the negative control which was $45.60 \%$, the low concentration of 0.001 had more inhibition effect on MI than 0.1 plant extract concentration but close to 0.01 concentration action. The lowest number of cmetaphase cells (2.00) obtained in samples treated with 0.01 plant extract for four hours (4 hours) compared to the positive control which was (26.33) cells in c-metaphase.

Table( 1 ): Mitotic index and C- Metaphase in Allium cepa L. root tips treated with C. cornigera aqueous leaves extract and $0.05 \%$ colchicines.

\begin{tabular}{|c|c|c|c|c|c|c|c|c|c|c|c|c|}
\hline \multirow{2}{*}{$\begin{array}{c}\text { Treatme } \\
\text { nt } \\
\mathrm{Mg} / \mathrm{ml}\end{array}$} & \multicolumn{4}{|c|}{4 hours } & \multicolumn{4}{|c|}{6 hours } & \multicolumn{4}{|c|}{12 hours } \\
\hline & T.C. & D.C. & $\begin{array}{c}\text { M.I.\% } \% \\
\text { S.D. }\end{array}$ & $\begin{array}{c}\text { C-M } \pm \\
\text { S.D. }\end{array}$ & T.C. & D.C. & $\begin{array}{l}\text { M.I.\% } \\
\pm \text { S.D. }\end{array}$ & $\begin{array}{l}\text { C-M\% } \\
\pm \text { S.D }\end{array}$ & T.C. & D.C. & $\begin{array}{c}\text { M.I.\% } \% \\
\text { S.D. }\end{array}$ & $\begin{array}{c}\text { C-M土 } \\
\text { S.D. }\end{array}$ \\
\hline Neg. C & 1603 & 731 & $\begin{array}{c}45.60 \pm \\
13.90\end{array}$ & $\begin{array}{c}0.00 \pm \\
0.00\end{array}$ & 1483 & 493 & $\begin{array}{c}33.24 \\
\pm \\
8.17 \\
\end{array}$ & $\begin{array}{c}0.00 \pm \\
0.00\end{array}$ & 1389 & 378 & $\begin{array}{c}27.20 \pm \\
14.59\end{array}$ & $\begin{array}{c}0.00 \pm \\
0.0\end{array}$ \\
\hline Pos. C & 1680 & 525 & $\begin{array}{c}31.25 \pm \\
11.61\end{array}$ & $\begin{array}{c}26.33 \\
\pm \\
10.50\end{array}$ & 1272 & 356 & $\begin{array}{c}27.98 \\
\pm \\
2.16 \\
\end{array}$ & $\begin{array}{c}35.33 \\
\pm \\
7.234 \\
\end{array}$ & 1124 & 169 & $\begin{array}{c}15.03 \pm \\
5.511\end{array}$ & $\begin{array}{c}41.00 \\
\pm \\
25.06\end{array}$ \\
\hline $\begin{array}{c}0.1+ \\
0.05 \text { Col. }\end{array}$ & 1317 & 244 & $\begin{array}{c}18.53 \pm \\
3.589\end{array}$ & $\begin{array}{c}5.67 \pm \\
3.51\end{array}$ & 1464 & 183 & $\begin{array}{c}12.5 \pm \\
7.08\end{array}$ & $\begin{array}{c}1.33 \pm \\
0.577\end{array}$ & 1876 & 256 & $\begin{array}{c}8.90 \pm \\
1.76\end{array}$ & $\begin{array}{c}4.33 \pm \\
3.78 \\
\end{array}$ \\
\hline $\begin{array}{c}0.01+ \\
0.05 \text { Col. }\end{array}$ & 1074 & 86 & $\begin{array}{c}8.00 \pm \\
3.83\end{array}$ & $\begin{array}{c}2.00 \pm \\
1.00\end{array}$ & 1397 & 368 & $\begin{array}{c}26.34 \\
\pm \\
7.50\end{array}$ & $\begin{array}{c}2.00 \pm \\
1.00\end{array}$ & 1221 & 156 & $\begin{array}{c}12.88 \pm \\
4.36\end{array}$ & $\begin{array}{c}8.00 \pm \\
5.56\end{array}$ \\
\hline $\begin{array}{c}0.001+ \\
0.05 \text { Col. }\end{array}$ & 1120 & 85 & $\begin{array}{c}7.59 \pm \\
4.15\end{array}$ & $\begin{array}{c}3.33 \pm \\
3.05\end{array}$ & 1280 & 382 & $\begin{array}{l}29.84 \\
\pm 7.30\end{array}$ & $\begin{array}{l}2.67 \pm \\
1.528\end{array}$ & 1144 & 160 & $\begin{array}{c}13.98 \pm \\
5.129\end{array}$ & $\begin{array}{c}8.33 \pm \\
5.85\end{array}$ \\
\hline
\end{tabular}

T.C. $=$ Total cells $\quad$ D.C. $=$ Dividing cells Negative Control Pos. C. =Positive Control

M.I. = Mitotic Index $\quad \mathbf{C}-\mathbf{M}=$ c-Metaphase

Neg. $C=$

The data revealed that the decrease in cmetaphase cells co-present with the decrease in mitotic index (MI) of treated cells with plant extract and colchicines. These decreases in MI are concentration dependent, while the decrease in cmetaphase cells was concentration independent.

The statistical analysis revealed no significant differences between groups and within groups total cells (TC) at time intervals. But there were significant differences between groups and within groups of dividing cells (DC) at 4 hours treatment with different plant extract concentrations $(\mathrm{P}=0.019)$. There were highly significant inhibitory effects on dividing cells in samples treated with different plant extract concentrations compared to positive and negative control between groups and within groups $(\mathrm{P}=0.003)$ by ANOVA analysis at time of 6 hours.

Table (1) showed a decline in C-metaphase cells at $0.1 \mathrm{mg} / \mathrm{ml}$ concentration which was 1.33 cells in cells treated to 6 hours compared to positive control which was 35.33 cells. By increasing the time to 12 hours, there were significant differences $(\mathrm{P}=$
0.012 ) between groups within groups on c-metaphase at different concentration $(\mathrm{p}<0.05)$, but there were not significant differences between groups within groups on dividing cells $(\mathrm{P}=0.193)$. ANOVA test indicated significant effect $(p<0.05)$ of plant extract on number of c-metaphase in treated sample with all concentrations compared to (positive and negative) control at all-time treatments, also it indicated a significant effect $(p<0.05)$ of plant extract on M.I.\% in treated samples compared to (positive and negative) control at (4 and 6) hours of time treatment.

\section{Genotoxicity of Cynara cornigera leaves aqueous extract}

The treatment of $A$. cepa root tip cells with different concentration of $C$. cornigera crude water extract $(0.1,0.01$ and $0.001 \mathrm{mg} / \mathrm{ml})$, for different exposure times $(4,6$ and 12$)$, the resulted data were presented in table (2).

No abnormal cells were observed at negative control treatment samples at all applied interval times. While at high concentration (positive control) 


\section{EPRA International Journal of Research and Development(IJRD)}

of $C$. cornigera leaves aqueous extract, the percentage of abnormal cells were increased (35.735, 51.034 and $44.123 \%$ ) by increasing time (4, 6 and 12 hrs), respectively. The percentage of physiological abnormalities at low concentration of $0.001 \mathrm{mg} / \mathrm{ml}$ were increased from $27.66 \%$ at $4 \mathrm{hrs}$ treatment to $29.06 \%$ at $6 \mathrm{hrs}$ and $29.86 \%$ at $12 \mathrm{hrs}$. However, at the time $4 \mathrm{hrs}$ of treatment there were increases in abnormality at high concentration of $C$. cornigera extract which were $35.735 \%, 40.264 \%, 33.091 \%$ and $27.666 \%$ at concentration of stock solution of 0.1 ,
0.01 and $0.001 \mathrm{mg} / \mathrm{ml}$, respectively. Increase of the treatment time to $6,12 \mathrm{hrs}$. with high concentration (stock solution) induce an increase in percentage of abnormalities (51.034 and $44.123 \%$, respectively) compared to $4 \mathrm{hrs}$ of time treatment which was $(35.735 \%)$. The most common type of physiological abnormalities which appeared in all the concentrations and periods of treatment are given in plate (2) and (3) and chromosomal stickiness at metaphase is more observed in all treatments.

Table (2): The effect of Cynara cornigera leaves aqueous extract on Mitotic Index \% and of Normal cells\% and Abnormal cells\% of $A$. cepa meristematic cells (Group 2).

\begin{tabular}{|c|c|c|c|c|c|c|c|c|c|}
\hline \multirow{2}{*}{$\begin{array}{c}\text { Treatment } \\
\mathrm{Mg} / \mathrm{ml}\end{array}$} & \multicolumn{3}{|c|}{4 hours } & \multicolumn{3}{|c|}{6 hours } & \multicolumn{3}{|c|}{12 hours } \\
\hline & $\begin{array}{l}\text { M.I.\% } \\
\pm \text { S.D. }\end{array}$ & $\begin{array}{c}\text { N.C. } \\
\pm \\
\text { S.D. }\end{array}$ & $\begin{array}{c}\text { Ab. C. } \\
\pm \\
\text { S.D. }\end{array}$ & $\begin{array}{l}\text { M.I.\% } \pm \\
\text { S.D. }\end{array}$ & $\begin{array}{l}\text { N.C. } \% \pm \\
\text { S.D. }\end{array}$ & $\begin{array}{l}\text { Ab. C. \% } \\
\pm \text { S.D. }\end{array}$ & $\begin{array}{c}\text { M.I.\% } \\
\pm \\
\text { S.D. }\end{array}$ & $\begin{array}{c}\text { N.C. } \\
\% \pm \\
\text { S.D. }\end{array}$ & $\begin{array}{l}\text { Ab. C. } \\
\pm \text { S.D. }\end{array}$ \\
\hline Neg. C. & $\begin{array}{c}8.666 \pm \\
0.733\end{array}$ & $\begin{array}{c}100.0 \\
\pm \\
0.00\end{array}$ & $\begin{array}{c}000.0 \pm \\
0.00\end{array}$ & $\begin{array}{c}8.929 \pm \\
0.559\end{array}$ & $\begin{array}{c}100.00 \pm \\
0.00\end{array}$ & $\begin{array}{c}000.00 \pm \\
00.00\end{array}$ & $\begin{array}{c}9.535 \pm \\
1.202\end{array}$ & $\begin{array}{l}100.00 \\
\pm 0.00\end{array}$ & $\begin{array}{c}00.00 \pm \\
00.00\end{array}$ \\
\hline $\begin{array}{c}\text { Stock } \\
\text { solution } \\
\text { (Pos. C.) }\end{array}$ & $\begin{array}{c}2.244 \pm \\
0.072\end{array}$ & $\begin{array}{c}64.265 \\
\pm \\
2.04\end{array}$ & $\begin{array}{c}35.735 \pm \\
2.042\end{array}$ & $\begin{array}{c}2.378 \pm \\
0.194\end{array}$ & $\begin{array}{c}48.966 \pm \\
0.32\end{array}$ & $\begin{array}{c}51.034 \pm \\
0.56\end{array}$ & $\begin{array}{c}0.323 \pm \\
0.129\end{array}$ & $\begin{array}{c}55.877 \\
\pm \\
0.466\end{array}$ & $\begin{array}{c}44.123 \pm \\
0.466\end{array}$ \\
\hline $0.1 \mathrm{mg} / \mathrm{ml}$ & $\begin{array}{c}3.748 \pm \\
0.28\end{array}$ & $\begin{array}{c}59.736 \\
\pm \\
1.25\end{array}$ & $\begin{array}{c}40.264 \pm \\
1.092\end{array}$ & $\begin{array}{c}3.230 \pm \\
0.15\end{array}$ & $\begin{array}{c}72.39 \pm \\
0.35\end{array}$ & $\begin{array}{c}27.610 \pm \\
0.615\end{array}$ & $\begin{array}{c}3.544 \pm \\
0.374\end{array}$ & $\begin{array}{c}73.317 \\
\pm \\
0.552\end{array}$ & $\begin{array}{c}26.683 \pm \\
0.552\end{array}$ \\
\hline $0.01 \mathrm{mg} / \mathrm{ml}$ & $\begin{array}{c}4.792 \pm \\
0.198\end{array}$ & $\begin{array}{c}66.909 \\
\pm \\
3.89 \\
\end{array}$ & $\begin{array}{c}33.091 \pm \\
1.358\end{array}$ & $\begin{array}{c}4.419 \pm \\
0.322\end{array}$ & $\begin{array}{c}69.455 \pm \\
0.355\end{array}$ & $\begin{array}{c}30.546 \pm \\
0.616\end{array}$ & $\begin{array}{r}3.983 \pm \\
0.574\end{array}$ & $\begin{array}{c}74.183 \\
\pm \\
1.902\end{array}$ & $\begin{array}{c}25.817 \pm \\
1.90\end{array}$ \\
\hline $0.001 \mathrm{mg} / \mathrm{ml}$ & $\begin{array}{c}5.814 \pm \\
0.826\end{array}$ & $\begin{array}{c}72.334 \\
\pm \\
0.694\end{array}$ & $\begin{array}{c}27.666 \pm \\
0.629\end{array}$ & $\begin{array}{c}5.601 \pm \\
0.176\end{array}$ & $\begin{array}{c}70.936 \pm \\
0.102\end{array}$ & $\begin{array}{c}29.063 \pm \\
0.177\end{array}$ & $\begin{array}{c}5.122 \pm \\
0.504\end{array}$ & $\begin{array}{c}70.134 \\
\pm \\
0.178\end{array}$ & $\begin{array}{c}29.866 \pm \\
0.178\end{array}$ \\
\hline
\end{tabular}

M.I. =Mitotic Index. $\quad$ Ab. C. \%=Percentage of abnormal cells. $\quad$ N.C. =Percentage of normal cells. Neg. C. =Negative Control. Pos. C. =Positive Control. S.D. =Standard Deviation.

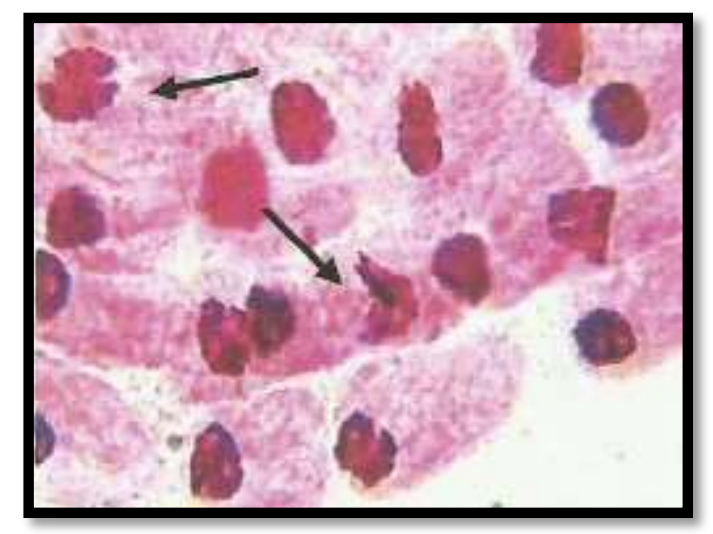

Disturbed nuclear shape (stock solution at 12hr). 


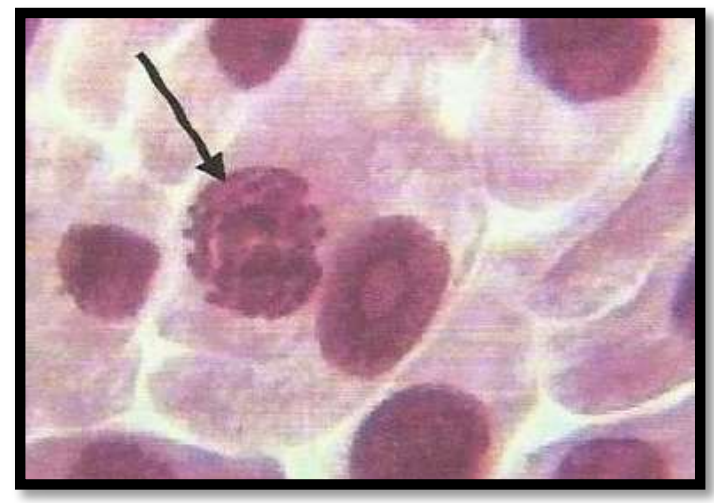

Highly condensation prophase (stock solution at $\mathbf{4 h r}$ ).

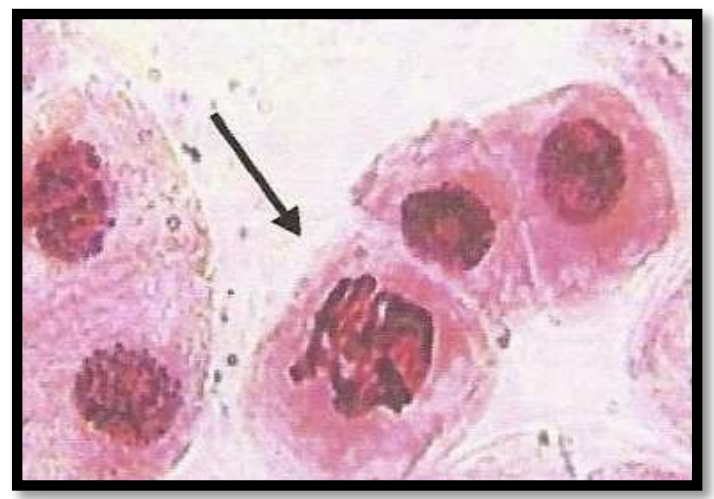

Early condensation propha (0.1 $\mathrm{mg} / \mathrm{ml}$ at12hr).

Plate (2) Physiological abnormal mitotic cells of $A$. cepa root tip cells after treatment with different concentrations of $C$. cornigera leaves aqueous extract for different periods.

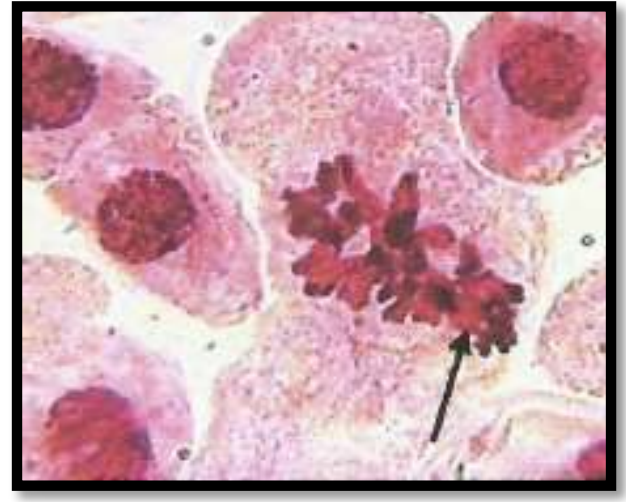

Stick metaphase(0.01 mg/ml at $6 \mathrm{~h})$.

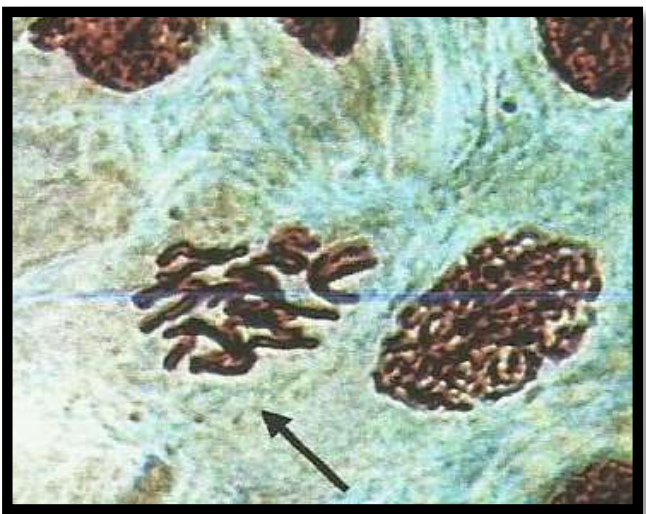

C-metaphase $(0.1 \mathrm{mg} / \mathrm{ml}$ at $6 \mathrm{~h})$

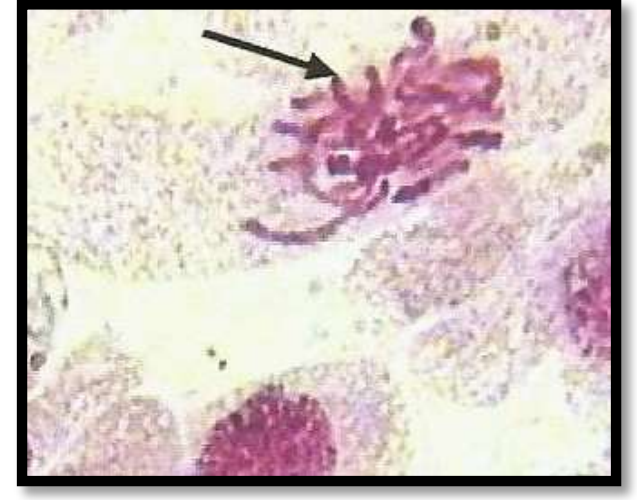

C- metaphase (positive control at $4 \mathrm{~h})$.

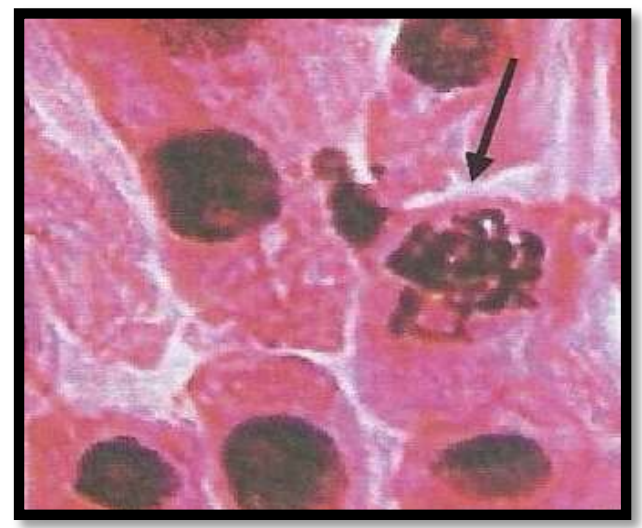

Plate (3) Physiological abnormal mitotic cells of Allium cepa tip cells after treatment with different concentrations of $C$.cornigera leaves aqueous extract for different periods. 


\section{SJIF Impact Factor: 6.260| ISI I.F.Value:1.241| Journal DOI: 10.36713/epra2016 \\ EPRA International Journal of Research and Development(IJRD)}

\section{DISCUSSION}

A. cepa root tip meristems have been widely used for evaluation of cytotoxic and antimitotic activity of various compounds (Fiskesjo, 1988; Soliman and Ghoneam, 2004 and Sehgel et al. , 2006). Such mitotic inhibition could result of the inhibition of DNA synthesis which is considered as one of major perquisites for a cell to divide (El Garabulli and Mohamed, 2007). However the reduction of mitotic activity after treatment could be associated with a reduction in the amount of both DNA and RNA (Badr, 1986; Soliman and Ghonium, 2004). Many other investigators attributed the depression in mitotic index values to the inhibition of protein synthesis, or due to inhibition of certain types of nuclear proteins essential in mitotic cycle (Haliem, 1990; Turkoglu, 2008; Ghareeb et al., 1997 and ELNahas, 2000). Similar results were obtained by (Medeiros and Takahashi 1987), who reported a decrease in mitotic index in onion root tip cells at all tested concentrations.

The mitotic index values were decreased with increasing of $C$. cornigera concentration and exposure time, especially at high concentration (stock solution) compare to control. This result is in agreement with action of other plant extract proved to be mitodepressive such as: the effects of castor (Ricinus communis) seed extract on Allium cepa root tip cells, effects of water extract of Rosmarinus officinalis on Alium cepa root tips, the mutagenic effects of water extract of ten Ipomoea species on root tip cells of onion, genotoxic effect of seed decoction of Cassia tora L. (languminaosae) in A. cepa root tip cells (Borah and Talukder, 2002; Tawab et al. , 2004; Mondel et al. , 2006, and Solanke et al. , 2008), respectively.

The percentage of chromosomal abnormalities decreased at lower extract concentration but it was found to be increased with high concentration. Such results agree with those obtained by Kaushik et al., (1993), who tested water extract of Datura stramonium on $A$. cepa root tip cells. They found that the mitodepressive effect of plant extract were increased with increase the concentration and exposure time.

The present experiment also showed that different concentrations of $C$. cornigera extract induced various forms of chromosomal aberration and the aberrant rate goes up with the concentrations. The treatment of $A$. cepa with different concentration of $C$. cornigera water extract induced only physiological types of chromosomal abnormalities which represented by chromosomal stickiness at metaphase and early prophase condensation. No damage of genetic material was observed such as fragment, bridge and micronucleus, which mean the third way suggested by Xiao-wei, 2004, is not the mechanism of $C$. cornigera action of cell dress inhibition.

The percentage of physiological aberration was increased by increased of $C$. cornigera extract concentration and exposure time, these observations agreed with other reports (Ragunathan and Panneerselvam et al. , 2007; Solanke et al. , 2008; Mahanta et al. ,2008). The most common type of physiological abnormality observed in all the concentrations and periods of treatment was, chromosomal stickiness at metaphase, this even may be due to alteration of chromosomal proteins resulting in change in surface nucleoprotein configuration or improper folding in chromosome fiber (Saggoo et al., 1991).

The mitotic index inhibition of root tips of $A$. cepa $L$. at different concentrations and exposure period times, indicated that $C$. cornigera plant has positive antimitotic effects. The data obtained from this study suggested that using extracts of $C$. cornigera plant is a good and safe method and can be used as antioxidant and anticancer agent. Therefore, more investigation using molecular methods most take in account with more attention.

\section{REFERENCES}

1. Badr, A. 1986. Effects of the S-Triazine Herbicide Turbutryn on mitosis, Chromosomes and Nucleic Acids in Root Tips of vicia faba. Cytologia, 51:571-577.

2. Borah, S. P. and Talukder, J. 2002. Studies on the Cytotoxic Effects of Extract of castor seed (Ricinus communis L.). cytologia, 67(3):235-243.

3. El-Garabulli, F. R. and Mohamed, S. A. 2007. Use of random amplified polymorphic DNA (RAPA) for the detection of the brominal herbicide genotoxicity. The $10^{\text {th }}$ International Chemistry Conference and Exhibition in Africa (10 ICCA). Benghazi, Libya.

4. El-Nahas, A.; Khalifa, S. and Abu El-Enein, M. 2000. Karyological studies on the solanaceae. Pakis. J. of biolo. Sci., 3(5): 717- 720.

5. El-Toriki, M.; Mehdi, A. W.; Mohammed, A. and Al-Jiboori, N. 2006. Liver and kidney function in adult male rats following multiple subcutaneous injection of non- lethal doses of Datura metel leaves Aqueos extract. Sci. and their appli. , 1:919.

6. Fiskesjo, G. 1988. The Allium test- an alternative in environmental studies: the relative toxicity of metal ions. Mutat. Res., 197, 243- 260. Fiskesjo, G.1993. The Allium test. In: Wastewater Monitoring. Environ Toxicol Water Qual 8: 291298.

7. Fransworth, N. R. 1994. Ethnopharmacology and drug development. In Chadwick, D. J., and Marsh, J., (eds). Ethnobotany and Search for 
New Drougs, CIBA Foundation Symposium 185, John Wiley and Sons, Chichester, New York, PP 44-51.

8. Ghreeb, A. and George, N. 1997.Cytotoxic of insecticide Temic 15G (Decarb) in mitosis and meiosis of cells of Vicia faba plant, Cytologia, 62: 259-263.

9. Grant W. F. 1982. Chromosome aberration assays in Allium: A report of the U.S. Environmental protection Agency Gene-Tox Program. Mutation Research. 99:273-291.

10. - Haliem, A. S. 1990. Cytological effects of the herbicide sencor on of Allium cepa. Egypt. J. Bot. 33: 93-104.

11. Iranbakhsh, A.; Ebadi, M. and Bayat, M. 2010. The Inhibitory Effect of Plant Methanolic Extract of Datura Stramonium L. and Leaf Extract Callus Against Bacteria and Fungi. Global Veterinaria, 4(2): 149-155.

12. Jafri, S. M. H. and El-gadi, A. 1983. Flora of Libya. Department of Botany, Al-Faath Univ., Tripoli, Libya, 107: 249- 250.

13. Jain, A. K. and Sethi, N. 1991. Chromosomal aberration and sister chromatid exchanges in culture human lymphocytes I. induced by crude extracts of black and green tea. Cytologia, 56:533-538

14. Kaushic, G.; Singh, V. and Yadav, S. 1993. Mitodepressive effects of Datura stramanium fruit extract on Allium cepa root tips. J. of Indian Boyan. Society. , 72(1-2): 85-88.

15. Mahanta, j.; Chetia, M.; Hazarika, C.; Narain, K. and Sharma, K. 2008. Toxicity of tuibur, unique form of tobacco smoke extract used in Mizoram India. Cytologia, 68(2)111-117.

16. Marzi, V.; Lattanzio, V. and Vanadia, S. 1975. II Carciofo Pianta Medicinale.

17. Palo, Bari: Ed. Liantonio.

18. Mederios, M. and Takahashi, G. 1987. Effects of Luffa operculata on Allium cepa Root tip cells. Cytologia. 52: 255-259.

19. Mondal, A.; Kabir, G.; Yasmin, N.; Alam, A. M. and Khatun, H. A. 2006. Mitotic Effect of Water Extract of Different Ipomoea species on Allium cepa L. Pakistan Journal of Biological sciences, 9 (6): 11161120 .

20. Nune, W. B. and Caravalho, S. DE. 2003. Evaluation of the mutagenic potential of Cochlospermum regium in Drosophila melanogaster male sperm cells. Genet. Mol. Bio. 26(4) 545- 549.

21. Ragunathan, I. and Panneerselvam, N. 2007. Antimutagenic Potential of curcumin on chromosomal aberration in Allium cepa. Journal of Zhejiang University science, 8(7): 470-475.

22. Saggoo, M. I., Kumari, S., and Bindu. 1991. Cytological effects of Indian medicinal plants IMitotic effects of leaf homogenate of Tylophora indica L. on Allium cepa. Cytologia, 65: 633-637.

23. Sehgal, R.; Roy, S. and Kumar, V. 2006. Evalution of cytotoxic potential of latex of calotropis procera and podophyllotoxin in Allium cepa root model. Biocell, 30: 9-13.

24. Solanke, P.; Singh, M.; Rthore, H. S.; Sharma, A.; Makwana, M. and Shrivastava, S. 2008. An evaluation of the genotoxic effects of seed Decoction of Cassia tora L. (Legumin osae) in Allium cepa model. Gene. And mol. Bio. , 23(2): 497-507.

25. Soliman, M.; and Ghoneam, G. 2004. The mutagenic potentialities of some herbicides using Vicia faba as a biological system. Biotechnology, 3(2):140-154.

26. Sonnante, G.; De Paolis, A.; Lattanzio, V. and Perrino, P. 2002. Genetic variation in wild and cultivated artichoke revealed by RAPD markers. Genetic Resources and Crop Evolution, 49: 247252.

27. Tawab, S. A. F.; Adam, Z. M. and Selmi, S. H. 2004. Suppression of Mitotic process Associated with Metaphase Arrest Allium cepa L. Roots using: 1. Rosmarinus officinalis L. Water Extract. Internation Journal of Agriculture and Biology, 4: 689-697.

28. Turkoglu, S. 2008. Evaluation of genotoxic effects of sodium propionate, calcium propionate and potassium propionate on the root meristem cells of Allium cepa. Food chem. Toxicol. , 46(6): 2035-41.

29. WHO. 1980. The WHO expert Committee on Diabetes mellitus. Technical Report Series NO. 646. World Health Organisation, Geneva, 1980.

30. Xiao-Wei, Q. 2004. Mutagenic effect of chromium trioxide on root tip cells of Vicia faba. J. of Zhejiang University science. , 5(2): 1570-1576. 